\title{
Contemporary issues and challenges of health sector in Nigeria
}

\author{
Omoleke I.I., *Taleat B.A.
}

\begin{abstract}
This paper examined the contemporary issues and challenges of the Nigerian health sector. It also attempted to identify the effect of the issues and challenges on the Nigerian citizens' health condition. The paper utilised primary data by interacting with randomly selected medical doctors, pharmacists, image scientists and nurses to elicit facts and information on issues, challenges and problems they experience in their hospitals. The findings of their experiences revealed that constellation of social, economic and environmental challenges are being experienced from hospitals, ranging from brain drain, poor remuneration, obsolete infrastructure, inadequate medical facilities and underfunding of the hospitals. The paper concluded that the Nigerian health system is defective when compared with developed countries and even with few African countries.
\end{abstract}

Key words: Health sector, Hospital management, Health policy, Health care delivery.

*Correspondence author

Taleat B.A.

http://orcid.org/0000-0003-4745-095X

Email: abioduntaleat@gmail.com

Department of Public Administration, Obafemi Awolowo University, Ile-Ife, Nigeria

Research Journal of Health Sciences subscribed to terms and conditions of Open Access publication. Articles are distributed under the terms of Creative Commons Licence (CC BY-NC-ND 4.0). (http://creativecommons.org/licences/by-nc-nd/4.0).

http://dx.doi.org/10.4314/rejhs.v5i4.5 


\title{
Enjeux contemporains et défis du secteur de la santé au Nigeria
}

\author{
Omoleke I.I., *Taleat B.A.
}

\begin{abstract}
Resume
Cet article a examiné les enjeux et défis contemporains du secteur de la santé nigérian. Il a également tenté d'identifier l'effet des problèmes et des défis sur l'état de santé des citoyens nigérians. Le document utilisait des données primaires en interagissant avec des médecins, des pharmaciens, des scientifiques de l'image et des infirmières choisis au hasard pour obtenir des faits et des informations sur les problèmes, les défis et les problèmes qu'ils rencontrent dans leurs hôpitaux. Les résultats de leurs expériences ont révélé que les hôpitaux sont confrontés à une multitude de problèmes sociaux, économiques et environnementaux: exode des cerveaux, rémunération médiocre, infrastructure désuète, installations médicales inadéquates et sous-financement des hôpitaux. Le document a conclu que le système de santé nigérian est défectueux par rapport aux pays développés et même avec peu de pays africains.
\end{abstract}

Mots clés: secteur de la santé, gestion hospitalière, politique de santé, prestation de soins de santé.

*Correspondence author

Taleat B.A.

http://orcid.org/0000-0003-4745-095X

Email: abioduntaleat@gmail.com

Department of Public Administration, Obafemi Awolowo University, Ile-Ife, Nigeria

Research Journal of Health Sciences subscribed to terms and conditions of Open Access publication. Articles are distributed under the terms of Creative Commons Licence (CC BY-NC-ND 4.0). (http://creativecommons.org/licences/by-nc-nd/4.0).

http://dx.doi.org/10.4314/rejhs.v5i4.5

Res. J. of Health Sci. Vol 5(4), Oct./Dec., 2017 


\section{INTRODUCTION}

The health sector of the Nigeria Economy is statutorily established to provide essentially health care services to Nigerians irrespective of their locations within the territorial jurisdiction of Nigeria (1). In short, the health sector belongs to the concurrent legislative list which empowers the Federal, the State and the Local Governments to legislate on health matters. So, the health care delivery services in Nigeria, as well as the National Health Policy, aim at addressing the provision of intensive, effective and efficient health care services to the people of Nigeria in order to allow them achieve laudable goals of health standard such that everyone will enjoy life at all levels of human endeavor. This statutory provision lends credence to the popular adage of "Health is Wealth" and of course, this is an irrefutable statement of fact as for example, if the rich have health challenges, his wealth is of no use to him. This assertion buttresses the significance of the health sector in any nation.

The health sector's principal concern is the safety of lives and good health and decent environment. However, its activities involve governmental and non-governmental institutions in a multi-sectorial approach as well as individuals and groups for effective planning and implementation of health care delivery services in the country.

The myriad of problems facing the Nigerian health care sector could be analysed using the various levels of health care (the three tiers of health care) involved in health policy formulation, implementation and monitoring, that is, the Primary Health Care managed by the Local Government, the Secondary Care administered by the State Government and Tertiary Care under the control of the Federal Government. In brevity, the health care delivery services channel the course of intergovernmental relations (2)

In Nigeria, the first major point of contact of the populace with the health care is the Primary Health Care facilities nationwide. In essence, the pivot of health care delivery services is the Primary Health Care under the Administration of Local Government Councils in the country. Its mission or central focus is basically on preventive care. The secondary and tertiary health institutions provide curative care and render supervisory and complementary services. They also receive referral cases from the Primary and Secondary levels as the case may be. The Federal Ministry of Health formulates health policies and ensures that there is compliance in form of implementation by the Hospitals Management Boards, hospitals and health institutions/agencies.

We would like to recall that the concept of health is still with multifarious problems/challenges in Nigeria and to this end, an attempt will be made to identify some of the major problems and challenges militating against the Nigeria contemporary health sector performance. It also highlights the solutions and offers prospects of Nigerian health care delivery services in the short and long run.

\section{Issues and Challenges of the Nigerian Health Sector}

The following are some but not limited to the contemporary issues and challenges of the Nigerian health care services delivery.

\section{Health Policy Formulation}

Perhaps the first step in identifying the health sector problems in Nigeria is to grope for health policy formulation organ and that is the Federal Government of Nigeria through the Federal Ministry of Health. In the first instance, the policies formulated are in most cases, one way traffic, meaning that Abuja initiative overwhelms the policies whereas a good policy must receive inputs from all stakeholders and the beneficiaries of the policy. Worse still, the policies even when they are formulated, lack proper coordination neither are they related to any economic target. Since Independence in 1960 , health policies had been enunciated in various forms either in the National Development Plans or as specific decisions. Furthermore, the political instability coupled with the unsettled economic order has also caused a serious setback to health care policy formulation, implementation, monitoring and evaluation. There has been no policy continuity owing to frequent changes of governance from the civilian to military and within the military and back to the civilian administration with different policies. In essence, good policies initiated by one regime were either frustrated or poorly implemented in contradiction to the intention which the originator of the policies had in mind.

\section{Human and Material Resources}

To start with, the location and distribution of human and material resources are often politicized such that health institutions are sited without adequate consideration of needs of the community. On the human resources, health 
personnel are still over stressed as Nigeria health sector is yet to meet the WHO template ratio 1 doctor to 500 patients (3). In some cases, the patients have to be on sitting down queueing for hours and if there is a serious case among them the patient may die. This is too bad! Furthermore, the staffs of hospitals are not adequately motivated like their counterparts in more civilized and civil countries. Related to the poor motivation of health workers is the problem of brain drain which is a bye product or consequential effects of frustration and poor motivation. Training and retraining of staff are poorly addressed in the health sector perhaps owing to the lean budgetary allocation to the health sector by the Federal Government year in year out, with little or no improvement. This leads us to another serious problem being experienced in the present day Nigeria and that is gross underfunding.

\section{Underfunding of the Health Sector}

Gross underfunding is a serious social cankerworm devouring the fabrics of the Nigerian health institutions. As a result of the lean budgetary allocation to the health sector, the Nigerian health system is below the World Health Organisation Standard of $15 \%$ of the total budget. By implication, the fund is not adequately budgeted for and released, timeously to the health institutions, the life-saving organizations for that matter. This gross underfunding of the health sector has been an issue for years. In the late 1980 s, external aids in form of technological know-how and personnel were affected by Nigeria's political imbroglio and democratization sanction. Then most medical exchange programmes that often assist health care delivery services were not forthcoming thus creating problems.

\section{Weak Facilities/Infrastructure}

Arising from the gross underfunding of the health sector institutions is the weak infrastructure and logistic supports which are weak, obsolete and defective. This is due to inadequate maintenance of buildings, medical equipment and vehicles, shortage of drugs, faulty compounding of drugs, poor management of drugs, the expiry of drugs and vaccines and other essential requirements for patients care. The utility Boards in Nigeria often make the problem worse by engaging in irregular supply of water, erratic or rather epileptic supply of electricity and poor telecommunication services. Absence or inadequacy of equipment had been found deficient in most of Nigerian Hospitals. Some of the public hospitals visited sometimes ago had no $\mathrm{x}$-ray machine. Worse still, the poor network of roads and neglect of roads transportation do not make accessibility easy. Hence, most patients referred from the primary level of care, or secondary find it difficult to get to where they can obtain a respite for their ailment and most times worsen the case that ordinarily requires minor treatment.

\section{Poor Motivation of Health Workers}

The health professionals in Nigeria are yet to be adequately remunerated like their counterparts in other advanced countries of the world. The consequential effects of poor motivation are facile. Such effects include frustration, poor service delivery, psychological warfare at work, industrial strikes and brain drain, just to mention few absurdities arising from poor motivation. Furthermore, various immunization programmes put in place under Preventive Medical Care have not been very successful to meet WHO standard due to few problems confronting implementation of immunization policy/programme. For instance, the storage of vaccine which requires cold condition is often defective.

The immunization officials contacted complained of poor remuneration, inaccessibility of rural areas as they are landlocked, worse still the roads are bad. Regrettably, it appears that the Nigerian Government seems to have been trivializing theories of motivation (theory $\mathrm{X}$ and Y) (4) and of course the implication of this attitude is low productivity and poor performance. This is not in tandem with good administration of health care delivery.

\section{Insecurity Challenges}

A corollary to the above is the unsettled political order, insecurity of life and property coupled with the restlessness of the Youths and Avengers who believe that there is no equity in the distribution of national wealth to Niger Delta geopolitical zone. So in a situation where hostage of citizens with heavy demand for ransom before release, kidnapping and bumping are continuous daily or weekly occurrence, implementation of health policy in such hostile environments is a mirage/ruse and is handicapped as no doctors, pharmacists, nurses, image scientists and laboratory technologists or Chief Medical Directors would want to lose their life untimely or prematurely. Monitoring and evaluation of health policy implementation in such hostile 
environment is also in question.

\section{Political and Bureaucratic Corruption}

Policy Implementation, Monitoring and Evaluation in the health sector is a challenge in a country where corruption has gone deep, tearing the fabrics of the society. Unarguably, corruption is a misnomer. It replaces meritocracy with mediocracy. Corruption in health sector has gone far in such a way that, teaching hospital had being visited for accreditation of its facilities and human resources and Chief Medical Director hired temporary specialists e.g. cardiologists, image scientists pediatrics and psychiatrists etc. just to meet the percentage set by the visitors and after the accreditation, it is back to square one shortage of human resources. Another example of corruption and ethical indecency is diversion of patients to privately owned hospital by a public hospital doctor or pharmacist or nurse. This is unethical behaviour.

Corruption features nearly everywhere in Nigeria and it is a social virus which has almost destroyed efficiency, effectiveness and performance or organisations providing service delivery in Nigeria. You may also wish to see political corruption among the politicians. However, one advantage the health sector has is that each of the team has ethical oath if it ethically complies with e.g.

(1) Physician Oaths (Hippocratic Oath)

(2) Code of Ethics for Nursing Profession

(3) Pharmacist Oath etc.

The Declaration of Geneva (Physicians Oath Declaration) adopted by the General Assembly of the World Medical Association at Geneva, Switzerland, September 1948 and amended by $22^{\text {nd }}$ World Medical Assembly, Sydney, Australia, August 1968, is antithetic to corruption if complied with and respect strict senso. Again, like the Doctors' Hippocratic Oath, the Nurses pledge is in alignment with the anticorruption crusade.

Paradoxically, most of the rules of professional conduct are at times blatantly violated by some health workers for one personal reason or the other. Who have one time or the other gone on industrial strike contrary to item "d" "the health of my patients will be my first consideration". In the same vein, some nurses in the antenatal and labour wards in some hospitals have been notorious for being rude to patients and are said to have being in the culture of abusing pregnant women at the crucial stage of labour pain when they seriously need their care. This is also a very serious challenge in the obstetric department and in the hospitals in general. This type of behaviour is tantamount to battery and assault in the law of medicine and is actionable and punishable if the culprit is found guilty. Such action/attitude is also incompatible with their professional ethical codes.

\section{Health Sector Budget}

The Nigeria health sector budget is not impressive as it has never moved closer to World Health Organization template of $15 \%$ of the members' annual budget to be allocated to the health sector. This recalcitrant act of the Nigeria Governments, past and present is inimical to health care infrastructural development and save delivery services. It affects so many units of health development. The poor health financing arising from lean budget often results in weak and obsolete infrastructure in the hospitals, congestion of patients to access health care because of limited human resources, poor supply of water, wards congestion, irregular supply of electricity, weak telemedicine facility and recruitment, training and retraining of staff of hospitals etc. Nigerian hospitals are "mere consulting clinics without drugs, dressings, water and electricity" (5). What a serious challenge that is surmountable but not well addressed by the Nigeria Governments, an oil producing state for that matter.

\section{Federal Governments Breach of Agreements}

It appears that Federal Governments of Nigeria have a tendency to breach any agreement duly signed with tertiary institutions. To this end, the other party has no option except to embark on industrial action which had happened in Nigeria teaching hospitals when doctors, pharmacists and nurses abandoned their duties. The effect of breach of contract by the Federal Government now leads us to another serious challenge of Industrial Strike. Yet the Nigeria Constitution recognizes the importance of health when it states in Section 17 Subsection 3(c) "The state shall direct its policy towards ensuring that the health safety and welfare of all persons in employment are safeguarded and not endangered or abused", (1) what a paradox!

\section{Inter Professional Conflicts \\ Unfortunately, investigation and} empirical research revealed that interprofessional conflicts are rife in the hospitals. Such conflicts have been smouldering among the professionals in the hospitals, especially among the nurses, pharmacists and doctors. The causes 
of such conflicts seem to bother on unnecessary rivalry and envy. We want to submit that such cutthroat conflicts and inferiority complex can breed professional animosity and this can affect the patients in their care. When two elephants fight, the grass suffers.

\section{Use of Telemedicine}

This is also a technological development in the health sector and it constitutes a challenge in the Nigeria health sector because of poor electricity, the internet and weak communication system being experienced in Nigeria.

\section{Solution and Future Prospect of the Nigeria Health Sector}

In spite of the inherited challenges/problems and the new challenges of today in Nigeria, hope is not lost in overhauling the system to meet the standard that citizens can benefit from. However, in order to build a sustainable, reliable, accessible and standard health sector, hospitals, medical centres, health centres, health post, clinics and other health institutions should be brought to the required standard of the World Health Organization at both curative and preventive levels of health administration. These institutions must also be well equipped with modern medical gadgets, structural facilities and uninterrupted electricity supply, portable water, internet provision, and good communication system across all the wards, offices and hospital environment.

As life-saving institutions, it is a trite fact and of course irrefutable that hospitals require service specialization in various health fields such as medicine, surgery, gynecology, obstetrics, psychiatry, pediatrics, cardiology, public health among others. To this end, there is need for meticulous selection/recruitment of hospitals staff. It is also necessary to train and retrain the human resources on the ground for health technological updating as knowledge get rotten and obsolete if not renewed. Development is a continuous phenomenon. The staff must also be promoted when due, motivated and remunerated accordingly. If these are addressed well, the level of performance will be raised hence high level productivity.

There is also a need to depoliticize allocation of funds to tertiary health institution and should be based on the approved appropriation Act/the needs of each hospital. Training of medical experts is a complex one which requires specialized training in Universities Teaching Hospitals. The various
State Governments and private organisations have also established Nursing Schools and Health Technology for the training of middle level manpower in the Health Sector. To this end, the Federal, State and Local Governments must be ready and willing to finance these institutions generously.

For effective human resources development and utilization, the owners and managers of the hospitals must not wait until doctors, pharmacists, nurses, image scientists, laboratory technologists and hospital administrations go on industrial strikes before their grievances are addressed. This is a more civil manner to handle issues that affect human life and well-being.

Intra and inter union conflicts bothering on inferiority and superiority complex among health professionals should be put to rest bearing in mind that health care delivery services are a team work involving all and sundries. Hence harmonious relationship is a sine-qua-non for effective health care delivery services anywhere in the world.

To this end, it is our opinion that training facilities in the universities, tertiary health institutions and teaching hospitals be adequately expanded and funded generously. A situation where a graduated medical doctor, as an example will have to wait around for months before security placement of horsemanship is frustrating and absurd. It is disheartening to observe that after (57) fifty seven years of independence, Nigeria Government is yet to develop her human resources in the health sector to meet or draw close to WHO's template.

In addition, Government should expand hospitals, medical centres and health clinics to absorb the newly trained and inducted doctors, pharmacists etc., as it may be a waste of fund, time and human resources if health professionals are trained by Nigeria Government only to be utilized by other countries (Brain Drains). The situation calls for the urgent attention of the Federal Government of Nigeria.

More importantly, Governments of Nigeria must bear in mind that capital needs labour and vice versa. Labour should not be enslaved by the Employer. The relationship between the two parties (Employee and Employer) must be symbiotic and harmonious in order to achieve organizational set goals of healthy citizens. It should not be a master/servant relationship at all. If the identified challenges and problems are sincerely addressed as analysed in the foregoing discussion, the future prospect of 
the Nigeria health sector is prosperous.

\section{CONCLUSIONAND RECOMMENDATION}

We thereby conclude that the Nigeria Health Sector is replete with inadequacies and shortcomings and weaknesses in the areas of capital, material and human resources which hinder effective health care delivery services. The Nigeria Health Sector can only be improved if Nigeria statesmen are less self centred but much more committed to health policy formulation, implementation, monitoring and evaluation. Significantly, the Nigeria Medical Association (NMA) must also insist that necessary facilities are put in place so that doctors can be encouraged to uphold professionalism as negligence is presumed until the contrary is proved.

We should note that in law, the hospitals and the owner are liable for the negligence of their servants and there is a liability also whether the doctors do not act for reward or not. Both the principal and agent (Hospital Owners and Workers) are vicariously liable for any negligence arising from inadequacies and challenges in the health sector. Thus, the Federal Ministry of Health, the Hospitals Management Board, the State Minister of Health, the Chief Medical Director and the entire hospital are liable for the negligence in the health system.

On a final note, we want to conclude by drawing the attention of the Federal Government of Nigeria to the words of Adam Smith; "No society can surely be flourishing and happy of which greater part of its members are unhealthy, poor and miserable" (6). This scholar solicits for unreserved support and full commitment of the political elite, health policy makers, and power elite in charge of public affairs to accord topmost priority to issue bothering on the health care delivery system so that Nigeria can be ranked as advanced country at least in health jurisdiction. Once again health matters should not be subjected to political rhetorics and bureaucratic red tapism or rigmarole as life has no duplicate.

Conflict of interest: The author declares no conflict of interest.

\section{REFERENCES}

1. The Constitution of the Federal Republic of Nigeria 1999 as amended in 2011.

2. Omoleke, I.I. "The Primary Health Care Services in Nigeria: Constraints to Optional Performance", NJM, 2005 Vol. 14, No. 2

3. WHO "Annual Report", 2006

4. McGregor D. "The Human Side of Enterprise". International Student Edition.
Mcgraw-Hill Kogakusha, Ltd, 1960

5. The Nation, Thursday, July 19, 2012, p. 43

6. Adam S "The Wealth of Nations", London, Penguin Books, 1759 